\title{
Dominguez, Iñaki (2020): Macarras interseculares. Una historia de Madrid a través de sus mitos callejeros. Santa Cruz de Tenerife: Melusina, 457 pp. ISBN: 978-84-15373-83-4.
}

Iñaki Dominguez es un filósofo y antropólogo que se está dedicando a estudiar la cultura contemporánea de un modo riguroso y, al tiempo, ameno. Engarza con una larga tradición dentro de los Estudios Culturales, que por desgracia no ha tenido mucha presencia en nuestro país ni a nivel editorial ni dentro del mundo académico. Entre sus obras anteriores encontramos Sociología del moderneo (2017), Signo de los tiempos. Visionarios, locos y criminales del siglo XX (2018), Cómo ser feliz a martillazos. Un manual de antiayuda (2018) y El expiador. Vida y obras de Charles Manson (2019). En ellos se analizan las subculturas juveniles, el consumo, la llamada industria de la felicidad o la vida de personajes especiales, marginales o criminales. Su último libro, que reseñamos aquí, marra una especial y personal historia de Madrid a través de sus "macarras".

El concepto de macarra, que etimológicamente hace referencia al proxeneta, es entendido aquí como el de un individuo, varón y urbanita, que vive en el límite de la legalidad y que utiliza la violencia para imponerse a los demás. Un individuo joven, un "chulo" que vive en la calle y suple sus limitaciones intelectuales con el recurso de la violencia. Aparece en entornos urbanos, pero precisamente en el límite entre la ciudad y la emigración rural. Es un pícaro moderno, pero el macarra "quiere imponer su voluntad de modo directo, al descubierto. Si el pícaro se guía por argucias subrepticias, el chulo hace más uso de la violencia y de la intimidación" (2020: 24). En toda la obra se hace hincapié en el origen familiar del macarra: suelen provenir de familias desestructuradas en las cuales se aprende que la violencia es un recurso válido para solventar los problemas que plantea la existencia.

El libro se basa en entrevistas en profundidad. Iñaki Dominguez parece haber recorrido la ciudad de Madrid de punta a punta entrevistando a macarras y a personas que conocieron y convivieron con los macarras. Algunos de estos tratan de ocultar su pasado, del que no reniegan, pero del cual no se sienten del todo orgullos, y narran su vida bajo seudónimo. Pero otros, de un modo que puede sorprender al lector, lo hacen a cara descubierta, narrando sus "hazañas" en un tono jactancioso. Es más, algunos incluso han proporcionado abundantes fotografías para que Iñaki Dominguez las incluya en el libro. Las fuentes primarias se complementan con entrevistas periodísticas y referencias novelas, películas, grupos musicales y programas de televisión. Esto no debe resultar extraño, pues en las narraciones de los macarras existe una referencialidad constante a la cultura popular.

Porque esta historia de Madrid es una historia de las mitologías de la calle. Y estos mitos no son históricos, aunque escondan un cierto pasado factual. El valor de los mitos no descansa en su "realidad", sino en su misma capacidad de perpetuarse y transmitirse. Como afirmaba Roland Barthes: "El mito es un valor, su sanción no consiste en ser verdadero" (2009: 180). Además, los actores, en este caso, los macarras son consciente del valor del mito y lo utilizan creativamente. Muchos de ellos heredan o usurpan los motes de otros macarras para aprovechar la mitología asociada a ese nombre en su favor.

En muchas ocasiones el mito se construye en diálogo con la cultura popular. En Macarras Interseculares esto aparece constantemente: ciertas películas o grupos musicales fueron utilizados como fuente de inspiración por los chulos y macarras de barrio. La relación entre la delincuencia juvenil y las películas de gangsters fue señalada desde los estudios culturales británicos (Hall y Jefferon, 2000; Hebdige, 1974a, 1974b y 1974c, 2001). Del mismo modo, los jóvenes macarras patrios iban al cine, a ver películas del llamado "Cine Quinqui" (que, por cierto, últimamente está recibiendo mucha atención: González del Pozo, 2020; Whittaker, 2020) o escuchaban música (desde los Chunguitos, los Chichos o los Calis hasta el heavy, el rap - la música electrónica) y adaptaban a su ambiente las pautas culturales que consideraban más afines a su situación.

Iñaki Dominguez presta mucha atención a lo largo del libro a la extracción social del macarra. Existen macarras en todos los estratos sociales, aunque predominan entre las clases populares. Sin embargo, las posibilidades del macarra vienen condicionadas por su clase social. Los macarras de clase alta, las "ovejas negras" de la elite, tienden a realizar operaciones ilegales de mayor volumen e importancia y, debido a sus contactos, suelen salir mejor parados cuando tienen problemas con la policía y la judicatura. Además, si logran superar su etapa como macarras, tienden a incorporarse a la sociedad en puestos acordes a su clase social de origen. Los macarras de clase social menos favorecida realizan delitos de menor entidad $y$, sin embargo, son tratados más duramente por las autoridades. Además, cuando superan la etapa del macarreo se convierten en trabajadores no cualificados. En todo caso, y en esto coinciden todas las clases, muchos de los macarras acaban mal: viven vidas al límite de la ley y de la salud, física y mental, y muchos de ellos las viven por un corto periodo de tiempo. Es como si sus conductas destructivas para con los demás terminaran revirtiendo en ellos mismos.

En todas las narraciones surgen pautas comunes: la vida nocturna, a través de sus bares, pubs y discotecas; el consumo de alcohol y de drogas, y también las adicciones y el trapicheo; la violencia: muchos de los 
macarras se preparan activamente, además, para ejercerla, pues practican boxeo, culturismo o artes marciales y la ejercen incluso de modo recreativo, pues quedan para "pegarse" sin una finalidad definida más allá de mantener su prestigio; o el sexo y las mujeres, aunque estas aparecen más como un telón de fondo, una recompensa ligada a la vida peligrosa del macarra. El macarreo se inscribe, además, dentro de las pautas subculturales propias de la juventud. En muchas ocasiones el macarra es el representante más extremo de determinadas tribus urbanas o subculturas juveniles: mods, rockers, skins o, entre otras, punkies.

Un elemento importante es el tono del libro. Se describe el mundo del macarra, en sus propios términos y mostrando las mitologías de la calle, pero sin caer en la "admiración" acrítica en la que lo hacen muchos estudiosos de estos fenómenos subculturales, sobre todo cuando no han vivido de primera mano la realidad descrita. El autor parece haber vivido la calle, o tener cierto conocimiento de esta. Por lo mismo, no se romantiza al macarra: este aparece como un ser violento y un tanto patético. La mitología de la calle, narrada por los mismos macarras, puede hacerlos pasar por un moderno Odiseo urbano. Sin embargo, la realidad es mucho más prosaica. En uno de los capítulos, uno de ellos, dedicado al tráfico de cocaína al por menor, al final reflexiona y dice que en su mundo eran tratados como estrellas, pero que fuera de él no eran nadie. Es el triste destino del macarra: temido y respetado en la esquina de su barrio, rechazado y menospreciado por las capas "respetables" de la sociedad.

El libro se cierra señalado que el macarra auténtico parece estar en retroceso en las calles y plazas de Madrid, pero que en la sociedad hiperconsumista y hedonista actual aparece como recreación en muchas expresiones culturales. Los nuevos artistas adoptan modos y poses del macarra, sin serlos realmente. Este revival, que se da en muchas esferas, surge de la búsqueda de la autenticidad. Porque "la autenticidad es un valor en alza en innumerables ámbitos, algo que se debe al hecho de que vivimos vidas cada vez menos auténticas $y$, naturalmente, anhelamos aquellos de lo que carecemos como cultura" (2020: 457). El macarra hace las veces del salvaje, al que tememos y envidiamos al mismo tiempo.

Encontramos, en definitiva, una estupenda aproximación a un arquetipo de la cultura moderna y a las mitologías asociadas al mismo. Un análisis, sin embargo, centrado en la realidad vivida por los propios macarras y no en las idealizaciones de su vida. El libro se encuentra dentro de la tradición de los Estudios Culturales, alejado de la glosa erudita, y centrado en la realidad del objeto de estudio. Ecléctico en lo metodológico y claro en su narrativa. Lo mejor, pensamos, es su capacidad de dejar hablar a los macarras, lo que nos permite sumergirnos en un mundo muchas veces lejano al lector en lo espacial, temporal o social.

\section{Referencias bibliográficas}

Barthes, R. (2009 [1957]): Mitologías. Madrid: Siglo XXI.

González del Pozo, J. ed. (2020): Quinqui Film in Spain. Peripheries of Society and Myths on the Margins. London: Anthen.

Hall, S. y Jefferson, T. (2000 [1975]): Resistance through Rituals. Youth Subcultures in Post-War Britain. London: Routledge.

Hebdige, D. (1974a): Reggae, Rastas and Ruddies. Style and the Subversion of Form. Birmingham: CCCS.

- (1974b): Subcultural Conflict and Criminal Performance in Fulham. Birmingham: CCCS

- (1974c): The Kray Twins. A Study of a System of Closure. Birmingham: CCCS.

- (2001 [1979]): Subculture. The Meaning of Style. London: Routledge.

Whittaker, T. (2020): The Spanish Quinqui Film: Delinquency, Sound, Sensation. Manchester: Manchester University Press.

Antonio Martín-Cabello

(D) https://orcid.org/0000-0002-3832-4663

Universidad Rey Juan Carlos, España antonio.martin@urjc.es

Recibida: 01-02-2020

Aceptada: 25-03-2020 